\title{
Coagulation Changes in Children with Sickle Cell Anaemia during Painful Crises and Steady State at Federal Medical Centre Abeokuta, Nigeria
}

\author{
Mukhtar Babajide Adebola1 ${ }^{*}$, Durotoye Michael Olanrewaju' ${ }^{2}$, Morufat Mojisola Ogundeyi ${ }^{1}$, \\ Khadijah Bolanle Shonde-Adebola ${ }^{3}$ \\ ${ }^{1}$ Paediatrics Department, Federal Medical Centre, Abeokuta, Nigeria \\ ${ }^{2}$ Department of Paediatrics, Olabisi Onabanjo University Teaching Hospital, Sagamu, Nigeria \\ ${ }^{3}$ Department of Haematology, University College Hospital, Ibadan, Nigeria \\ Email: ^mukdijah@yahoo.com
}

How to cite this paper: Adebola, M.B., Olanrewaju, D.M., Ogundeyi, M.M. and Shonde-Adebola, K.B. (2018) Coagulation Changes in Children with Sickle Cell Anaemia during Painful Crises and Steady State at Federal Medical Centre Abeokuta, Nigeria. Open Access Library Journal, 5: e5081. https://doi.org/10.4236/oalib.1105081

Received: November 29, 2018

Accepted: December 23, 2018

Published: December 26, 2018

Copyright $\odot 2018$ by authors and Open Access Library Inc.

This work is licensed under the Creative Commons Attribution International License (CC BY 4.0).

http://creativecommons.org/licenses/by/4.0/

\begin{abstract}
Background: The pathophysiology of vaso-occlusive crises in sickle cell anaemia (SCA) is multifactorial and hypercoagulability is believed to play a role. The association between hypercoagulabilty and vaso-occlusive disease has been extensively studied in adult SCA patients, there is however paucity of data on the subject regarding paediatric SCA. Objective: This study set out to determine the presence of hypercoagulable states specifically in paediatric SCA subjects through quantification of specific coagulation markers during painful crises and steady state. Methodology: The study was a hospitalbased longitudinal study carried out between May and October 2015 at Federal Medical Center, Abeokuta, Nigeria. Fifty SCA subjects were consecutively recruited during painful crises and followed up into their respective steady states. Twenty-five subjects with HbAA phenotype served as controls. Assays of coagulation markers, D-dimer and prothrombin fragment $(\mathrm{F} 1+2)$ were carried out by sandwich ELISA method using MyBiosource ${ }^{\circledR}$ D-dimer and F1 +2 ELISA kits. Results: Mean D-dimer level was $7358 \pm$ $4354.33 \mathrm{ng} / \mathrm{ml}$ in the SCA subjects during painful crises, $5509 \pm 3506.2 \mathrm{ng} / \mathrm{ml}$ during steady state, and $800 \pm 1874.14 \mathrm{ng} / \mathrm{ml}$ in HbAA controls. Mean (F1 + 2) level was $0.84 \pm 0.43 \mathrm{nmol} / \mathrm{l}$ in the SCA subjects during painful crises, 0.64 $\pm 0.25 \mathrm{nmol} / \mathrm{l}$ during steady state, and $0.41 \pm 0.28 \mathrm{nmol} / \mathrm{l}$, in HbAA controls. The mean values of both coagulation markers assayed were significantly higher during painful crises than at steady state $(P=0.002)$, while steady state values were also significantly higher than that of haemoglobin AA individuals
\end{abstract}


$(\mathrm{P}=0.001)$. Conclusions: This study suggests the presence of hypercoagulable states in paediatric SCA during steady state which is exacerbated during painful crises. The clinical imports of this finding require further elucidation.

\section{Subject Areas}

Pediatrics

\section{Keywords}

Sickle Cell Anaemia, Hypercoagulability, D-Dimer, Prothrombin Fragment

\section{Introduction}

Sickle cell disease (SCD) is an inherited haemolytic anaemia whose clinical manifestations arise from the tendency of the haemoglobin S (HbS) to polymerize and deform red blood cells into the characteristic sickle shape [1]. Acute vaso-occlusive pain is the cardinal feature of SCA [2] and is largely a consequence of mechanical obstruction to blood flow by sickled red cells as well as increased adhesion of red blood cells (RBC) and leucocytes to the vascular epithelium [3].

The presence of $\mathrm{HbS}$ results in a conformational change in the haemoglobin tetramer which causes the de-oxygenated HbS molecules to interact with each other to form the rigid polymers that give $\mathrm{RBC}$ the characteristic sickle shape [4]. Although this pathophysiological scheme constitutes the basic mechanism of the disease, and explains the haemolytic anaemia, and the mechanical aspects of vaso-occlusive crises (VOCs), it does not however account for the processes that actually trigger and perpetuate VOCs [5].

More recent findings have implicated $\mathrm{RBC}$ dehydration, abnormal RBC adhesion to the endothelium, inflammation, activation of blood cellular elements, abnormalities of vascular tone and nitric oxide (NO) metabolism, as well as coagulation activation in the pathogenesis of VOCs [6] [7] [8] [9] [10].

In spite of recent improvements in management, morbidity and mortality from SCA remain high in the West African sub-region. [11]. Painful crises are the hallmarks of SCA, and coagulation activation is now believed to play a role in the development of these crises [12] [13].

Previous studies [12] [13] [14] [15] have established the existence of hypercoagulable states with elevated fibrin D-dimer, prothrombin fragments and thrombin-antithrombin complex levels during steady state in SCA subjects which are exacerbated during painful crises and other complications of SCA. Many of these studies [12] [13] [14] have, however, been largely restricted to adult populations. Studies [16] [17] [18] have, interestingly, also established elevated levels of specific coagulation markers in relation to aging and smoking even in the absence of overt clinical cardiovascular disease. These latter findings limit the 
extrapolation of findings of elevated specific coagulation markers in adults SCA patients to paediatric populatons.

Furthermore, there is paucity of data on coagulation changes in paediatric SCA patients from the West African sub-region. Only one study by Fakunle et al. [13] from the sub-region which assayed Fibrin D-dimer in adult SCA subjects in Ibadan was available to these investigators; while none assaying more than one specific coagulation marker specifically in paediatric SCA patients has been reported from the Sub-region.

Chinawa et al. [19] evaluated clotting profiles in paediatric SCA subjects and demonstrated significantly prolonged PT and PTTK values during steady state and painful crises. This finding however suggests a predisposition to abnormal bleeding rather than thrombosis [20]. Furthermore, coagulation factors are known to normally circulate as inactive zymogens in significant concentrations. Elevated levels of clotting factors alone therefore do not confirm hypercoagulability [20], which is more reliably determined through direct measurement of markers of thrombin generation such as D-dimer, prothrombin fragment (F1 + @2) and thrombin-antithrombin complex (TAT).

This study therefore set out to determine the presence of a hypercoagulable state specifically in children with SCA during painful crises and steady state, through assay of specific coagulation markers, fibrin D-dimer and F1 +2 . It also seeks to examine the relationship between levels of these coagulation markers and objective assessment of pain in subjects.

\section{Methodology}

The study was a hospital-based longitudinal study carried out at Federal Medical Centre Abeokuta between May and October 2016.

\subsection{Study Setting}

The study was carried out at the Federal Medical Center (FMC), Abeokuta, a 250-bedded multi-specialist hospital which provides tertiary healthcare for inhabitants of Ogun state, as well as neighbouring South-western states of Nigeria.

The hospital's services include a weekly paediatric haematology clinic which has over 350 registered SCD subjects. The clinic holds every Tuesday with an average weekly attendance of 30 SCA patients, and is run by two Consultant Paediatric Haematologist assisted by two senior and junior resident each, as well as interns. The paediatric Unit also comprises of the Children's emergency room, the children's wards, the newborn unit as well as the paediatric general out-patient department.

\subsection{Study Population}

Fifty subjects who presented with painful crises and met the inclusion criteria were recruited for the study. These were confirmed SCA patients aged between 3

- 15 years who presented with painful crises at the children emergency room or 
haematology clinic at FMC Abeokuta. Three years is the minimum age for which the Oucher pain chart has been validated for application, while 15 years is the cut-off age for paediatric care at the FMC Abeokuta. Painful crisis was defined as acute painful episodes in SCA subjects not attributable to any specific aetiology [21] [22].

Subjects were consecutively recruited over a period of six months till the estimated sample size of fifty was reached. The same patients were followed up into their respective steady states which was taken as six weeks after resolution of painful crises or infections, or three months after the last blood transfusion [13]. The consents of care-givers were obtained, as well as assents of children aged 7 years and above.

SCA subjects with painful episodes with determined aetiologies, established disorders associated with hypercoagulability in children (specifically nephrotic syndrome and diabetes mellitus were screened for), other SCD variants obtained by $\mathrm{Hb}$ electrophoresis, as well as those who had been commenced on hydroxyurea, were all excluded from the study.

Twenty-five age and sex matched HbAA patients served as controls. These were apparently healthy individuals visiting the out-patient clinic for routine follow-up or pre-school entry examination.

The sample size was calculated using the Leslie Fischer formula. [23] with level of precision set at $4 \%$, and an anticipated attrition rate of $10 \%$

Ethical approval for the study was obtained from the institution's Research/ Ethics Committee. Voluntarily signed informed consent was obtained from the parents of all subjects and controls. Assents of children above seven years were also obtained. Confidentiality was maintained by allotting a serial number to each participant by which they were referenced at all stages of the study.

The sample collection process resulted in fleeting pain at puncture sites. Blood samples obtained specifically for the purpose of this study were processed at no cost to the patient, and the management of those patients who were unwilling to participate was not compromised by their non-participation.

\subsection{Materials}

The Oucher Pain Chart [24] was utilized to assign pain scores to subjects during painful crisis. This is a poster developed to help children communicate how much pain they feel. A picture matching the perceived degree of pain was selected from the chart and a corresponding score on a scale of 0 - 10 assigned. Caucasian, Hispanic, Asian and African-American versions of the chart have been developed. The African-American version of the chart was employed for this study.

D-dimer and F1 + 2 assays were carried out using MYBIOSOURCER ${ }^{\circledR}$ Human D-DIMER ELISA Kit [25] (Catalogue number: MBS723523) and MYBIOSOURCE ${ }^{\circledR}$ Human Prothrombin Fragment $1+2$ ELISA Kits [26] (Catalogue number: MBS701341) respectively. Platelet counts were determined using Sysmex $10001^{\circledR}$ 
Automated Haematology Analyzer.

D-dimer Reference value: $\leq 250 \mathrm{ng} / \mathrm{ml}$ [27].

F1 + 2 Reference value: $<0.3 \mathrm{nmol} / \mathrm{L}[28]$.

\subsection{Methods}

Five and one $\mathrm{ml}$ venous blood samples each were collected into plastic EDTA sample bottles by venipuncture from 50 consecutive SCA subjects during painful crises. Tourniquets were avoided as much as possible during sample collection. Tourniquet use, particularly when prolonged beyond 1 minute, is known to result in activation of coagulation factors and therefore may cause artefactual changes in coagulation profiles [29]. Pain scores were respectively assigned to each subject at the point of recruitment using the Oucher faces pain chart.

The venous samples for full blood count and the specific coagulation markers were obtained from participants within 72 hours of onset of painful crises. Similar steady state blood samples were obtained from the same patients at least 6 weeks after resolution of painful crises, or 3 months afterwards in those transfused during painful episodes.

Venous blood samples for full blood count and specific coagulation markers were also obtained from 25 control subjects who were apparently healthy closely matched HbAA subjects drawn from the Paediatrics Out-Patient Department. This group also had their haemoglobin phenotypes determined by electrophoresis using cellulose acetate strips.

The $5 \mathrm{ml}$ venous blood samples for coagulation marker assays were centrifuged at 3000 revolutions/min, and the platelet-poor plasma obtained aliquoted into plastic plain sample bottles and stored at $-80^{\circ} \mathrm{C}$. Plasma samples stored at this temperature remain viable for up to six months [25] [26]. D-Dimer and F1 +2 values were determined from these stored plasma samples by sandwich ELISA immunoassay using MyBiosource ${ }^{\circledR}$ ELISA kits

The $1 \mathrm{ml}$ EDTA venous blood sample was used for haemotogical profiles of subjects and controls using an automated haematology analyser.

Spot urine samples obtained from subjects and controls were analyzed for proteinuria, glycosuria and ketonuria, to screen for diabetes mellitus and nephrotic syndrome. These are two easily detectable disorders known to predispose to hypercoagulability in children. Patients with spot urinary protein $\geq 3+(\geq 300$ $\mathrm{mg} / \mathrm{dl}$ ) were to be evaluated for nephrotic syndrome and excluded, while patients with glycosuria were to be further evaluated for diabetes mellitus and those with random blood glucose values $\geq 200 \mathrm{mg} / \mathrm{dl}$ excluded.

\subsection{Data Management}

Pre-tested proforma were administered to subjects by interview method by the investigator and two trained assistants who were junior residents in the paediatrics department. Pain scores were assigned to patients in painful crisis using the Oucher chart and scores recorded. 


\subsection{Data Analysis}

Data were analyzed using Statistical Package for Social Sciences (SPSS), version 20.0. The significance of the differences between mean values expressed in contingency tables was tested using the paired sample t-test with level of significance set at $\mathrm{p}$-value $\leq 0.05$.

Pearson correlation coefficient was used to determine associations between $\mathrm{D}$-dimer and $\mathrm{F} 1+2$ values at $95 \%$ confidence interval, as well as the associations between both coagulation markers and the pain scores of the subjects.

\section{Results}

\subsection{Clinical Variables of Subjects and Controls}

A total of 50 SCA patients were recruited for the study consisting of 35 (70.0\%) males and 15 (30.0\%) females. Male-female ratio was 2.3:1. The control group consisted of 25 closely matched HbAA individuals, 15 (60.0\%) of which were males and 10 (40.0\%) females, giving a male-female ratio of 1.5:1 (Table 1).

The mean pain score using the Oucher pain chart was $5.07( \pm 2.2)$. Using the descriptive pain scale of mild (pain scores 1 - 3), moderate (4 - 6) and severe (7 10), majority of the subjects (52.2\%) presented with moderate pain, $26.1 \%$ with mild pain and $21.7 \%$ severe pain.

\subsection{Laboratory Variables of Subjects and Controls}

D-dimer values ranged from 840 to 15,660 ng/ml (mean: $7358 \pm 4354.33 \mathrm{ng} / \mathrm{ml}$ ) in the SCA subjects during painful crises, 320 to $13,200 \mathrm{ng} / \mathrm{ml}$ (mean: $5509 \pm$ $3506.3 \mathrm{ng} / \mathrm{ml})$ during steady state, and 90 to $8960 \mathrm{ng} / \mathrm{ml}(800 \pm 1874.14 \mathrm{ng} / \mathrm{ml})$ in HbAA controls. D-dimer value above $250 \mathrm{ng} / \mathrm{L}$ is elevated and suggestive of on-going thrombosis.

$\mathrm{F} 1+2$ values ranged from 0.06 to $1.81 \mathrm{nmol} / \mathrm{L}(0.84 \pm 0.43 \mathrm{nmol} / \mathrm{L})$ in the SCA subjects during painful crises, 0.07 to $1.11 \mathrm{nmol} / 1(0.64 \pm 0.25 \mathrm{nmol} / \mathrm{L})$ during steady state, and 0.05 to $1.21 \mathrm{nmol} / \mathrm{l}(0.41 \pm 0.28 \mathrm{nmol} / \mathrm{L})$ in $\mathrm{HbAA}$ controls. $\mathrm{F} 1+2$ values above $0.3 \mathrm{nmol} / \mathrm{L}$ are elevated.

The mean platelet count was $297 \times 10^{9} / \mathrm{L}$ during painful crisis, $306 \times 10^{9} / \mathrm{L}$ during steady state, and $235 \times 10^{9} / \mathrm{L}$ in HbAA controls (Table 1 ).

\subsection{Comparison of Laboratory Variables of Subjects and Controls}

The levels of both coagulation markers were significantly higher (D-dimer $\mathrm{p}=$ $0.02 ; \mathrm{F} 1+2 \mathrm{P}=0.01)$ during painful crises than in steady state amongst the SCA subjects as shown in Table 1 . There was however no significant difference between crisis and steady state platelet counts in the SCA subjects.

Table 2 shows that steady state levels of both coagulation markers, as well as platelet counts, were also significantly higher than those of HbAA individuals (d-dimer $\mathrm{P}=0.00 ; \mathrm{F} 1+2 \mathrm{P}=0.01$ ).

Mean d-dimer level during painful crises was about ten-fold that of the HbAA controls, whereas mean painful crises level of prothrombin fragment doubled 
that of HbAA controls as shown in Table 3.

There was, however, no significant correlation between grade of pain and both $\mathrm{D}$-dimer and prothrombin fragment levels $(\mathrm{r}=0.160 ; \mathrm{p}=0.228$ and $\mathrm{r}=0.116 ; \mathrm{p}$ $=0.453$ respectively) as shown in Figure 1 and Figure 2 respectively. Likewise, there was no significant correlation between d-dimer and prothrombin fragment levels in SCA patients during painful crises $(r=-0.063 ; p=0.673)$ as seen in Figure 3.

\section{Discussion}

Previous studies [12] [13] [14] have demonstrated evidence of thrombin generation in association with virtually all complications of SCA in adults. Given the heterogeneity of presenting symptoms in children with SCA, however, this study

Table 1. Comparison of mean values of coagulation variables for sca patients in steady state and vaso-occlusive crisis.

\begin{tabular}{ccccc}
\hline Coagulation Markers & $\begin{array}{c}\text { HbSS }(\mathrm{n}=50) \\
\text { Vaso-occlusive crisis } \\
\text { mean } \pm \text { SD }\end{array}$ & $\begin{array}{c}\text { HbSS }(\mathrm{n}=50) \\
\text { Steady State } \\
\text { mean } \pm \text { SD }\end{array}$ & $\mathrm{T}$ & $\mathrm{P}$ \\
D-Dimer(ng/L) & $7358(4354.33)$ & $5509(3506.21)$ & 2.34 & $0.02^{*}$ \\
Prothrombin fragments $(\mathrm{nmol} / \mathrm{L})$ & $0.83(0.43)$ & $0.64(0.25)$ & 2.70 & $0.01^{*}$ \\
Platelet count $\left(\times 10^{9} / \mathrm{L}\right)$ & $297(123.48)$ & $306(119.61)$ & 0.37 & 0.70 \\
\hline
\end{tabular}

${ }^{*} \mathrm{P}$-values $\leq 0.05$ are significant. There was a significant difference between mean values of both $\mathrm{D}$-Dimer and prothrombin fragment in SCA subjects during painful crisis compared with steady state.

Table 2. Comparison of mean values of coagulation variables for steady state sca patients and normal hemoglobin aa children.

\begin{tabular}{cccccc}
\hline Coagulation Markers & $\begin{array}{c}\text { HbSS }(\mathrm{n}=50) \\
\text { Steady state } \\
\text { mean } \pm \text { SD }\end{array}$ & $\begin{array}{c}\text { HbAA }(\mathrm{n}=25) \\
\text { Control } \\
\text { mean } \pm \text { SD }\end{array}$ & t & $\mathrm{P}$ \\
\hline D-Dimer $(\mathrm{ng} / \mathrm{L})$ & $5509.0(3506.21)$ & $800(1874.14)$ & 6.27 & $0.00^{*}$ \\
Prothrombin fragments $(\mathrm{nmol} / \mathrm{L})$ & $0.64(0.25)$ & $0.41(0.28)$ & 3.61 & $0.01^{*}$ \\
Platelet count $\left(\times 10^{9} / \mathrm{L}\right)$ & $306(119.6)$ & $235(92.81)$ & 2,60 & $0.01^{*}$ \\
\hline
\end{tabular}

${ }^{\star} \mathrm{P}$-values $\leq 0.05$ are significant. There was a significant difference between mean values of both $\mathrm{D}$-dimer and prothrombin fragment during steady state compared with those of HbAA controls

Table 3. Comparison of mean values of coagulation variable for scapatients in crisis and normal hemoglobin aa children.

\begin{tabular}{|c|c|c|c|c|}
\hline Coagulation markers & $\begin{array}{c}\operatorname{HbSS}(n=50) \\
\text { Vaso-occlusive crisis } \\
\text { mean } \pm \text { SD }\end{array}$ & $\begin{array}{c}\text { HbAA }(\mathrm{n}=25) \\
\text { Control } \\
\text { mean } \pm \mathrm{SD}\end{array}$ & $\mathrm{T}$ & $\mathrm{P}$ \\
\hline D-Dimer(ng/L) & $7358(4254.33)$ & $800(1874.14)$ & 7,34 & $0.00^{*}$ \\
\hline Prothrombin fragments(nmol/L) & $0.83(0.43)$ & $0.41(0.28)$ & 4.43 & $0.00^{*}$ \\
\hline
\end{tabular}




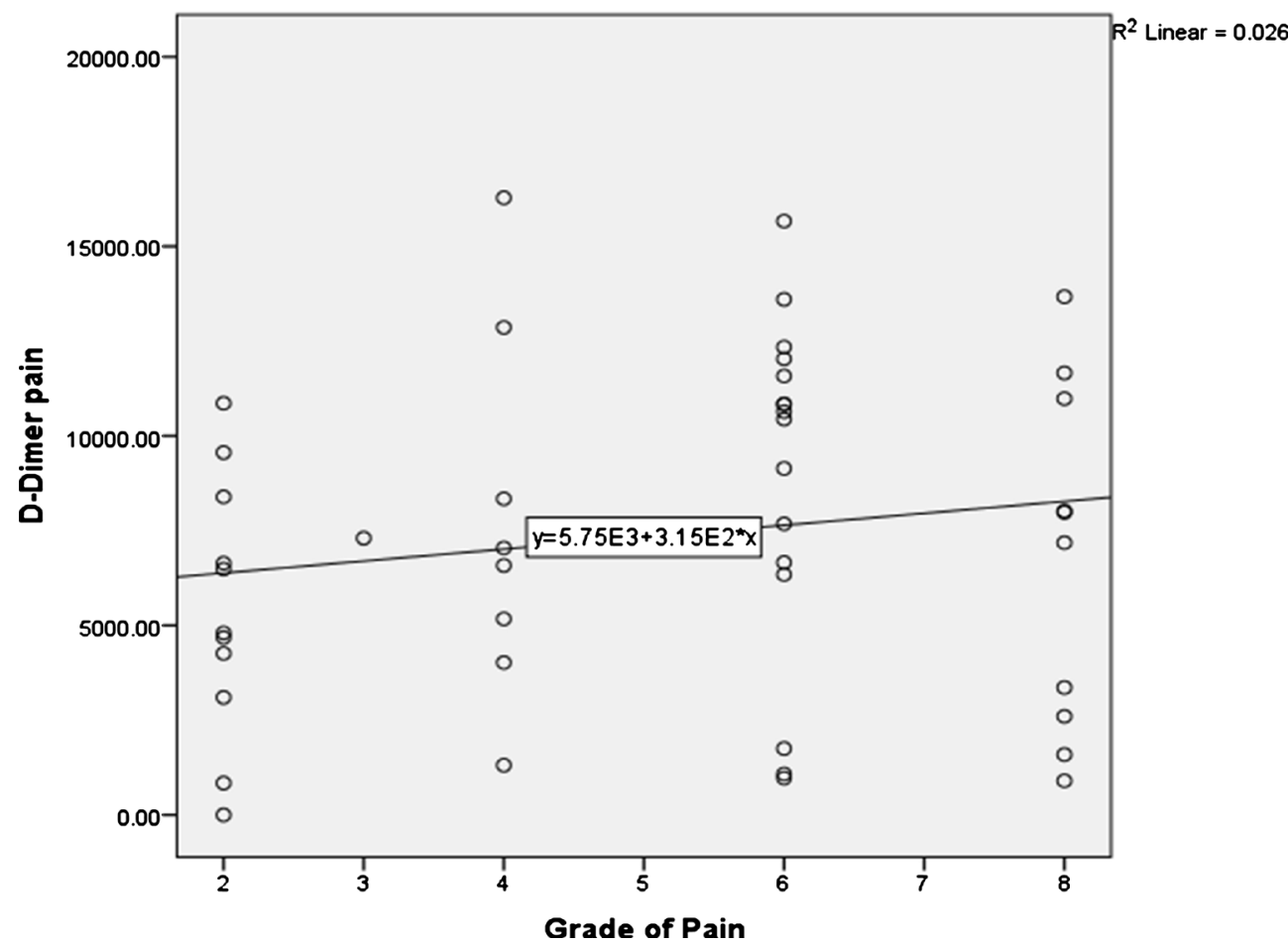

The graph shows that there was no significant correlation between D-dimer level during painful crisis and the pain scores of subjects in this study.

Figure 1. Scatter graph showing correlation between grade of pain and D-dimer levels in sickle cell crisis state $(\mathrm{r}=0.160 ; \mathrm{p}=0.228)$.

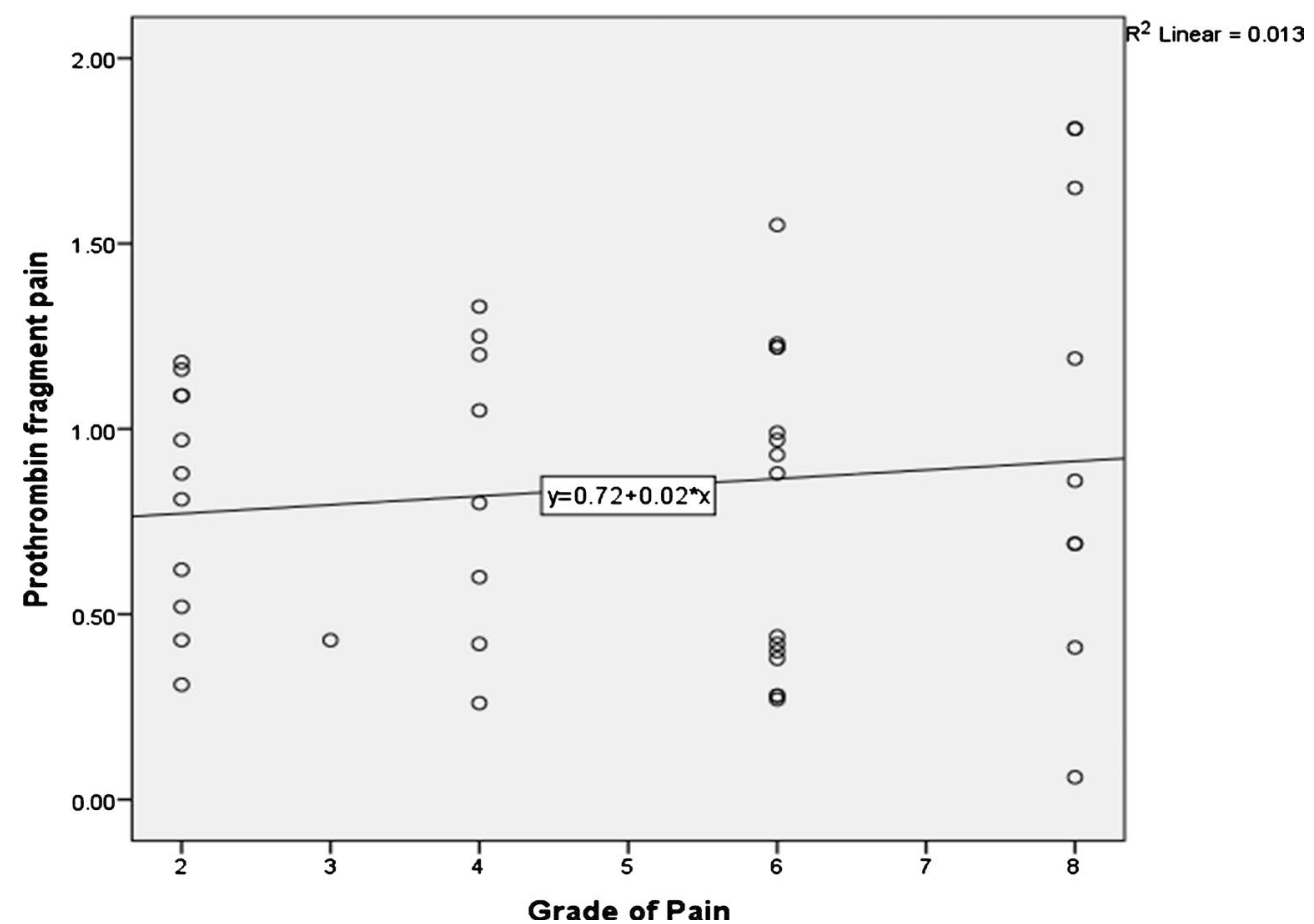

The graph shows that there was no significant correlation between prothrombin fragment level during painful crisis and the pain scores of subjects.

Figure 2. Scatter graph showing correlation between pain grade and Prothrombin fragment levels in sickle cell crisis state $(r=0.116 ; p=0.453)$. 


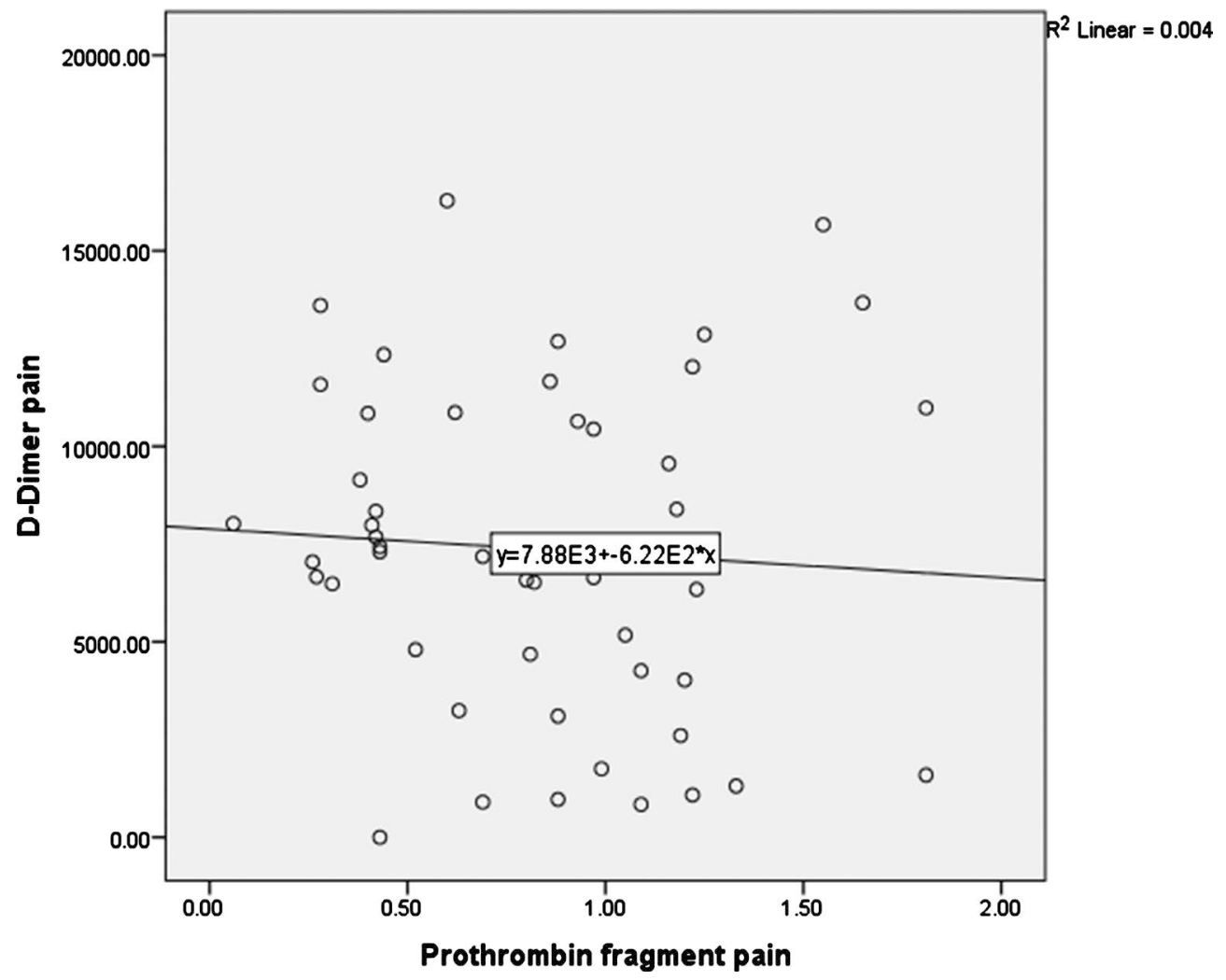

There was no significant correlation between D-dimer and prothrombin fragment levels in this study.

Figure 3. Scatter graph showing correlation between D-dimer and Prothrombin fragment levels in sickle cell crisis state $(\mathrm{r}=-0.063 ; \mathrm{p}=0.673)$.

restricted itself to painful crises as a common denominator across the recruited subjects.

This study demonstrated a significant increase in D-dimer and $\mathrm{F} 1+2$ levels in steady state compared to closely matched HbAA individuals, with a significant further increase during painful crises above steady state levels. This finding is indicative of on-going thrombin generation which is suficient evidence of coagulation activation in children with SCA during steady state with a further exacerbation during painful crises.

Although mean values for both coagulation markers were also above reference values in the HbAA controls, we demonstrated a statistically significant difference between the values of these markers in SCA subjects both during painful crises and steady state compared to the HbAA controls.

It should be noted also that 3 of the control subjects had considerably elevated levels of both coagulation markers which contributed to the high mean values obtained for the control group (Table 4). These are suspected to be artefactual, possibly due to difficult sampling. Although we did set out to specifically exclude nephrotic syndrome and diabetes mellitus, being two common childhood disorders that predispose to hypercoagulaility in children, we however did not evaluate subjects for levels of anti-coagulant proteins (such as proteins $\mathrm{C}$ and $\mathrm{S}$ ). Therefore we could not conclusively exclude the possibility of inherited or 
Table 4. Control subjects with unexplained elevated coagulation marker levels.

\begin{tabular}{ccc}
\hline SUBJECT & $\begin{array}{c}\text { D-DIMER }(\mathrm{ng} / \mathrm{L}) \\
\text { Ref: }<250 \mathrm{ng} / \mathrm{L}\end{array}$ & $\begin{array}{c}\mathrm{F} 1+2(\mathrm{nmol} / \mathrm{L}) \\
\text { Ref: }<0.3 \mathrm{nmol} / \mathrm{L}\end{array}$ \\
\hline CONTROL 12 & 8960 & 1.86 \\
CONTROL 14 & 3920 & 1.25 \\
CONTROL 15 & 1330 & 0.95 \\
\hline
\end{tabular}

acquired abnormalities of these proteins being responsible for the elevated levels observed in these $\mathrm{HbAA}$ controls.

Our findings are in agreement with previous studies in adult SCA subjects [12] [13] [14] which have documented similar observations from assays of specific coagulation markers either singly or in various combinations. These findings have however not been extrapolated to paediatric sickle cell anaemia subjects. Elevated levels of coagulation markers have interestingly been well documented [16] [17] [18] in apparently healthy adults in relation to aging, as well as in asssociation with smoking, even in the absence of overt clinical cardiovascular disease.

Both D-dimer and prothrombin fragment are specific coagulation markers, significant plasma levels of which represent sufficient evidence of in vivo thrombin generation [28] [30] Patients with SCA exhibit high plasma levels of markers of thrombin generation; depletion of circulating anticoagulants protein $\mathrm{C}$ and $\mathrm{S}$, increased tissue factor expression, as well as activation of platelets and other cellular elements which are chronically activated even in non-crises states.

This study also demonstrated significantly higher mean absolute platelet counts in subjects during steady state compared to HbAA controls (though the mean platelet counts were within normal limits in the three groups). This was similar to findings from Akinsegun et al. [31].

Chronic circulating platelets activation is known to occur in SCA, and contributes to the hypercoagulable state in this disorder. Activated platelets release agonists such as adenosine diphosphste (ADP), adenosine triphosphate (ATP), calcium, serotinin and coagulation factors into the surrounding milieu. In addition, platelets also provide the catalytic surface for he sequential activation of coagulation factors which culminates in thrombin generation [32]. Decreased bio-availability of $\mathrm{NO}$, a feature of $\mathrm{SCD}$, is also known to contribute to platelet activation in SCD, as reported by Ataga et al. [10].

This study however did not demonstrate a significant correlation between D-dimer and prothrombin fragment levels during painful crises. The time lapse following onset of painful crises may explain the insignificant correlation between the markers of coagulation [13]. Prothrombin is released during thrombin generation, while fibrin D-dimer is a product of fibrinolysis [28]. It should be noted that samples for both coagulation markers were obtained at the same point during crises and steady state respectively in this study. Although no specific time frame has been suggested for estimation of various coagulation mark- 
ers in hypercoagulable states, a previous study by Ota et al. [28] postulated that prothrombin fragment may be a more useful marker for the earlier phase of thrombosis whereas D-dimer reflects fibrinolysis after clot formation. The same study [28] also reported that Prothrombin fragment was observed to correlate better with thrombin-anti-thrombin (TAT) complex than with D-dimer. TAT was however not assayed in this study.

A significant correlation was not observed between pain scores and the levels of $\mathrm{D}$-dimer and prothrombin fragment in the present study. This corroborates findings from a similar study in adults by Fakunle et al. [13] Differences in individual pain thresholds make pain assessment a subjective clinical end point and may explain the insignificant correlation between pain scores and levels of specific coagulation markers in this study. Development of painful crises is also an interplay between several variables. Apart from the cellular mechanisms known to contribute to development of VOC, other extraneous factors such as extremes of temperatures, dehydration and infections also play a role. The precise levels of coagulation markers detectable at any point in time is also dependent on time elapsed since triggering of thrombin generation as well as the rate of fibrinolysis. [13] Some studies [7] [12] have reported that D-dimer levels correlate with the frequency of pain episodes measured during the following year as well as the interval for development of pain episodes in adult SCA subjects rather than the severity of painful episodes.

The findings from the present study suggest the presence of a hypercoagulable state in children with SCA detectable through assay of specific markers of coagulation, D-dimer and prothrombin fragment. The clinical imports of these findings however require further exploration and may chart a new course in the management of painful crises as well as other complications of sickle cell anaemia in children. It is postulated that amelioration of vascular occlusion pharmacologically would possibly be stronger evidence that the hypercoagulability contributes to vaso-occlusive complications of SCD [33]. Current practice is however largely empirical, and existing evidence on the benefits of these proposed interventions inconclusive [8] [33] [34] [35].

\section{Conclusion}

This study indicates the presence of a hypercoagulable state in children with SCA during steady state which is further exacerbated during painful crises. There was no significant association between levels of coagulation markers and severity of painful episodes in paediatric SCA subjects. The clinical implications of hypercoagulability in management of painful crises, as well as other complications of SCA, however require further investigations.

\section{Limitation}

This study was limited in not assaying for anti-coagulation proteins (C and S), deficiencies of which are known to contribute to hypercoagulability in SCD. This 
is particularly of importance in the light of the unexplained elevated levels of coagulation markers found in a number of the HbAA control subjects.

\section{Recommendations}

Multi-centre studies are required to further elucidate the role of hypercoagulability in complications of SCA, and possibly chart a new course in case management.

\section{Acknowledgements}

The authors wish to acknowledge the contributions of the following persons: $\mathrm{Dr}$ Olawale Olatunbosun whose painstaking sample analysis was invaluable to the outcome of this study; as well as Dr Igboanugo Somtochukwu for assistance with data collection and analysis.

\section{Conflicts of Interest}

The authors declare no conflict of interest and no external source of funding.

\section{References}

[1] Lal, A. and Vinchinsky, E. (2005) Sickle Cell Disease. In: Hoffbrand, A.V., Catovsky, D. and Tuddenham, E., Eds., Postgraduate Hematology, 5th Edition, Blackwell Publishing, USA, 104-108. https://doi.org/10.1002/9780470987056.ch7

[2] De Baun, M.R., Frei-Jones, M.J. and Vinchinsky, E.P. (2014) Hemoglobinopathies. In: Kliegman, R.M., Stanton, B.F., St Geme, J.W., Schor, N.F., Behrman, R.E., Eds., Nelson Textbook of Paediatrics, 20th Edition, Elsevier, Philadelphia, 2236-2245.

[3] Corrina, M. (2006) Sickle Cell Disease. In: Arceci, R., Hann, I. and Smith, O., Eds., Pediatric Hematology, Blackwell Publishing Ltd., 213-230.

[4] Beutler, E. (2010) Disorders of Hemoglobin Structue: Sickle Cell Anemia and Related Abnormalities. In: Kaushansky, K., Lichtman, M., Beutler, E., Kipps, T., Seligsohn, U., Prchal, J., Eds., Williams Hematology, McGraw-Hill Companies Inc.

[5] Odievre, M., Verger, E., Silva-Pinto, A.C. and Elion, J. (2011) Pathophysiological Insights in Sickle Cell Disease. Indian Journal of Medical Research, 134, 532-537.

[6] Ataga, K. (2012) Coagulation Activation in Sickle Cell Disease. Plos ONE, 7, 1-9. https://doi.org/10.1371/journal.pone.0029786

[7] Ataga, K.I. (2009) Hypercoagulability and Thrombotic Complications in Hemolytic Anemias. Haematologica, 94, 1481-1484. https://doi.org/10.3324/haematol.2009.013672

[8] Ataga, K.I. and Key, N.S. (2007) Hypercoagulability in Sickle Cell Disease: New Approaches to an Old Problem. ASH Education Program Book, 91-96.

[9] Ataga, K.I., Cappellini, M.D. and Rachmilewitz, E.A. (2007) Thalassaemia and Sickle Cell Anaemia as Paradigms of Hypercoagulability. British Journal of Haematology, 139, 3-13. https://doi.org/10.1111/j.1365-2141.2007.06740.x

[10] Ataga, K.I. and Orringer, E.P. (2003) Hypercoagulability in Sickle Cell Disease: A Curious Paradox. The American Journal of Medicine, 115, 721-728. https://doi.org/10.1016/j.amjmed.2003.07.011

[11] WHO (2006) Sickle Cell Anaemia. 59th World Health Assembly. Report by the Se- 
cretariat, Provisional Agenda Item 114.

[12] Devine, D.V., Kinney, T.R., Thomas, P.F., Rose, W.F. and Greenberg, C.S. (1986) Fragmenr D-Dimer Levels: An Objective Marker of Vaso-Occlusive Crises and other Complications of Sickle Cell Disease. Blood, 68, 317-319.

[13] Fakunle, E., Eteng, K. and Shokunbi, W. (2012) D-Dimer Levels in Patients with Sickle Cell Disease during Bone Pain Crises and in Steady State. Pathology and Laboratory Medicine International, 2, 21-25. https://doi.org/10.2147/PLMI.S29393

[14] Francis Jr., R. (1989) Elevated Fibrin D-Dimer Fragment in Sickle Cell Anemia: Evidence for Activation of Coagulation during the Steady State as Well as in Painful Crisis. Pathophysiology of Haemostasis Thrombosis, 19, 105-111. https://doi.org/10.1159/000215901

[15] Peters, M., Plaat, B.E., Ten Cate, H., et al. (1994) Enhanced Thrombin Generation in Children with Sickle Cell Disease. Thrombosis and Haemostasis, 71, 169-172.

[16] Bauer, K.A., Weiss, L.M., Sparrow, D., Vokonas, P.S. and Rosenberg, R.D. (1987) Aging-Associated Changes in Indices of Thrombin Generation and Protein C Activation in Humans. Journal of Clinical Investigation, 80, 1527-1534. https://doi.org/10.1172/JCI113238

[17] Cushman, M., Psaty, B., Macy, E., et al. (1996) Correlates of Thrombin Markers in an Elderly Cohort Free of Clinical Cardiovascular Disease. Arteriosclerosis, Thrombosis, and Vascular Biology, 16, 1163-1169. https://doi.org/10.1161/01.ATV.16.9.1163

[18] Hursting, M.J., Stead, A.G., Crout, F.V., Horvath, B.Z. and Moore, B.M. (1993) Effects of Age, Race, Sex and Smoking on Prothrombin Fragment 1.2 in a Healthy Population. Clinical Chemistry, 39, 683-686.

[19] Chinawa, J.M., Emodi, I.J., Ikefuna, A.N. and Ocheni, S. (2013) Coagulation Profiles of Children with Sickle Cell Anaemia in Steady State and Crisis Attending University of Nigeria Teaching Hospital Ituku-Ozalla, Enugu. Nigerian Journal of Clinical Practice, 16, 159-163. https://doi.org/10.4103/1119-3077.110132

[20] Hart, R.G. and Kanter, M.C. (1990) Hematologic Disorders and Ischemic Stroke. A Selective Review. Stroke, 21, 1111-1121. https://doi.org/10.1161/01.STR.21.8.1111

[21] Taiwo, I.A., Oloyede, O.A. and Dosumu, A.O. (2011) Frequency of Sickle Cell Genotype among Yorubas in Lagos: Implication of Level of Awareness and Genetic Counseling for Sickle Cell Disease in Nigeria. Journal of Community Genetics, 2, 13-18. https://doi.org/10.1007/s12687-010-0033-x

[22] Lande, W.M., Andrews, D.L., Clark, M.R., et al. (1988) The Incidence of Painful Crisis in Homozygous Sickle Cell Disease: Correlation with Red Cell Deformability. Blood, 72, 2056-2059.

[23] Araoye, M. (2004) Subjects Selection. In: Research Methodology with Statistics for Health and Social Sciences, Nathadex Publishers, Ilorin, 115-121.

[24] Pain Scales for Children. http://www.oucher.org/

[25] (2015) Mybiosource.

https://www.mybiosource.com/prods/ELISA-Kit/Human/D-Dimer-D2D/D2D/data sheet.php?products_id $=702820$

[26] (2015) Mybiosource. https://www.mybiosource.com/prods/ELISA-Kit/Human/Prothrombin-Fragment-1 -2/F1-2/datasheet.php?products_id=31213

[27] (2015). https://www.mayomedicallaboratories.com/test-catalog/Clinical+and+Interpretive/ 9290 
[28] Ota, S., Wada, H., Abe, Y. and Yamada, E. (2008) Elevated Levels of Prothrombin Fragment Indicate High Risk of Thrombosis. Clinical and Applied Thrombosis/ Hemostasis, 14, 279-285. https://doi.org/10.1177/1076029607309176

[29] Tampi, R. (2016) Preanalytical and Analytical Variables and Coagulation Tests. Clinipath Pathology.

[30] Soheir, S.A., Nigel, S.K. and Charles, S.G. (2009) D-Dimer Antigen: Current Concepts and Future Prospects. Blood, 13, 2878-2887.

[31] Akinbami, A., Dosunmu, A., et al. (2012) Haematological Values in Homozygous Sickle Cell Disease in Steady State and Haemoglobin Phenotypes AA Controls in Lagos, Nigeria. BMC Research Notes, 5, 396. https://doi.org/10.1186/1756-0500-5-396

[32] Scott, J.P. (2016) Platelet and Blood Vessel Disorders. In: Kliegman, R.M., Stanton, B.F., St Geme, J.W., Schor, N.F. and Behrman, R.E., Eds., Nelson Textbook of Pediatrics, 20th Edition, Elsevier, Philadelphia, 3604.

[33] Francis, R.B. (1991) Platelets, Coagulation and Fibrinolysis in Sickle Cell Disease: Their Possible Role in Vascular Occlusion. Blood Coagulation \& Fibrinolysis, 2, 341-354. https://doi.org/10.1097/00001721-199104000-00018

[34] Chaplin Jr., H., Monroe, M., Malecek, A., Morgan, L., Michael, J. and Murphy, W. (1989) Preliminary Trial of Minidose Heparin Prophylaxis for Painful Sickle Cell Crises. East African Medical Journal, 66, 574-584.

[35] Schnog, J.B., Kater, A.P., MacGillavry, M.R., et al. (2001) Low Adjusted-Dose Acenocoumarol Therapy in Sickle Cell Disease: A Pilot Study. American Journal of Hematology, 68, 179-183. https://doi.org/10.1002/ajh.1175 


\section{Appendices}

\section{Appendix I: Consent Form}

CONSENT TO PARTICIPATE IN THE STUDY: COAGULATION CHANGES

IN CHILDREN WITH SICKLE CELL ANAEMIA DURING PAINFUL CRISES AND STEADY STATE AT FEDERAL MEDICAL CENTER ABEOKUTA, NIGERIA.

Dear Parents/Guardians,

I am Dr Adebola, Mukhtar Babajide, a senior registrar in the department of Paediatrics, FMC, Abeokuta. I hereby seek your consent to participate in this study. Painful crises are the most common complication associated with sickle cell anaemia.

Although usually easy to recognize especially in older children, the diagnosis of painful sickle cell crisis is not always clear cut, and could easily be confused with other commonly encountered manifestations of SCD (e.g. as bone and soft tissue infections).

This study seeks to explore the potentials of the use of fibrin D-dimer and prothrombin fragment as objective laboratory markers for painful crises in SCA patients. It is also hoped that findings would contribute to better understanding of the disorder and possible emergence of new modalities for its management in children.

Your decision to participate in this study is voluntary, and your refusal to do so will not in any way compromise the care of your child/ward. You are also free to withdraw at any time. Confidentiality will also be maintained as much as possible throughout the course of this study.

If you decide to be part of the study, a questionnaire will be administered on your ward and $6 \mathrm{ml}$ blood will be obtained via venous blood sampling, which could cause mild fleeting pain at the injection site. Samples taken specifically for the purpose of this study will be processed at no extra cost to you and results of findings will be made known to you in simple terms.

Kindly indicate your consent by filling in your signature/thumbprint in the space provided below:

Name:

Relationship to patient:

Signature/thumbprint:

Witness:

Yours sincerely,

Dr M.B Adebola 
Appendix II: Oucher Pain Scale for Children

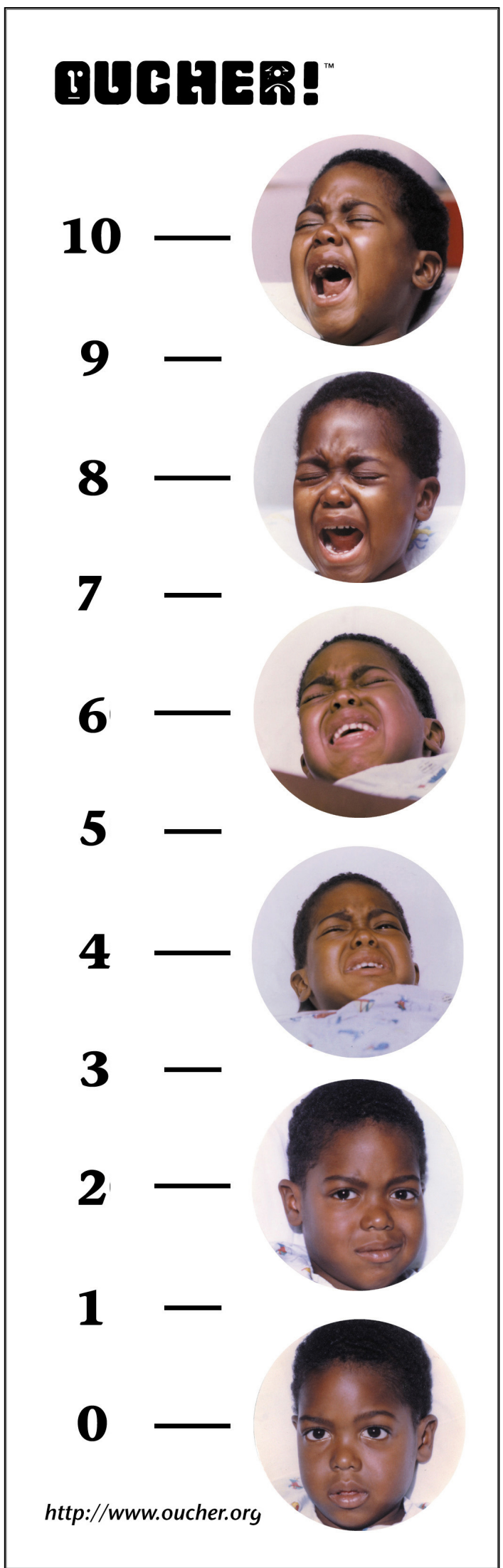




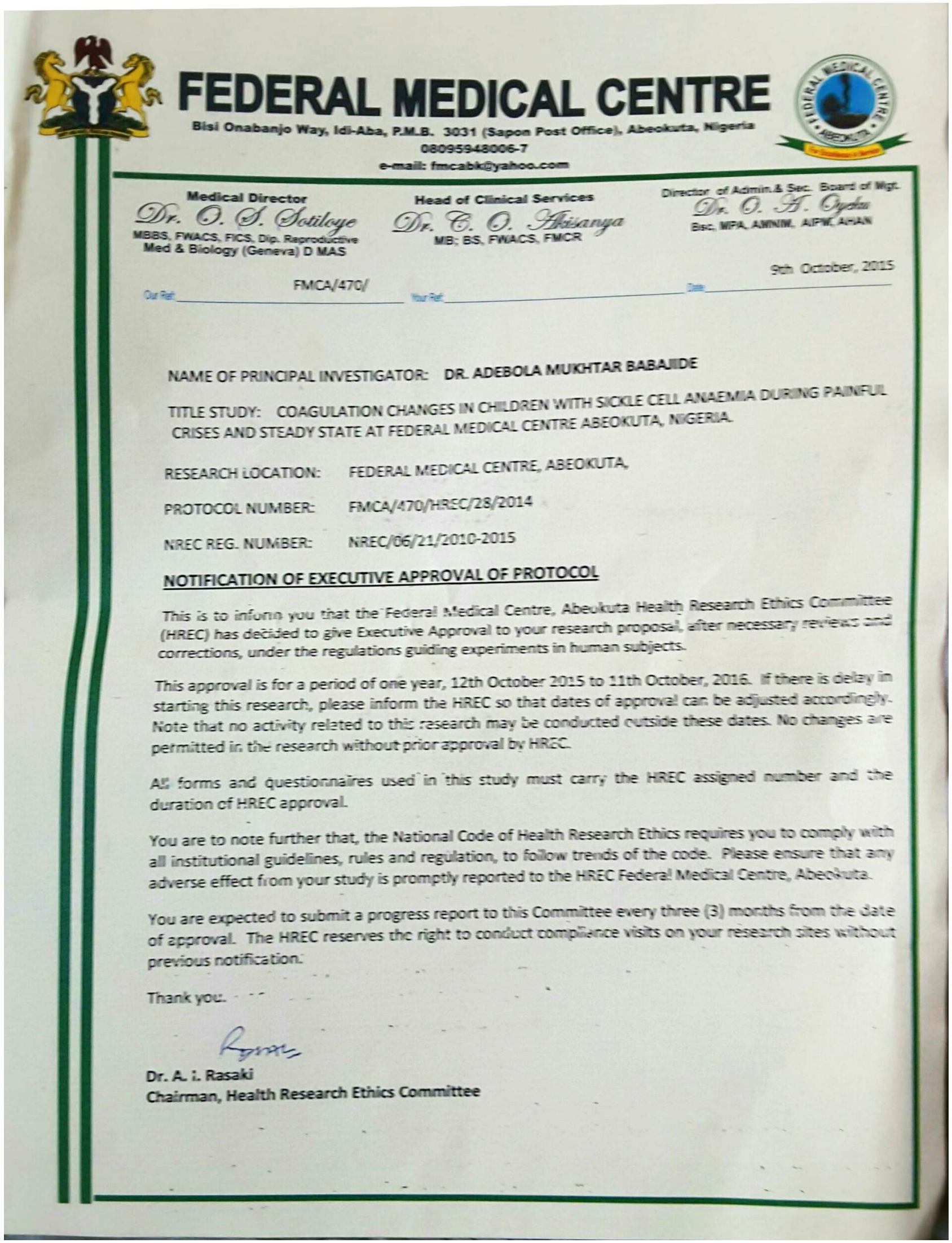

